\title{
Proksimat Pada Tepung Buah Mangrove Sonneratia alba
}

\author{
Putri Rahayu Ardiansyah ${ }^{1}$, Djuhria Wonggo ${ }^{*}$, Verly Dotulong ${ }^{1}$, Lena J. Damongilala, \\ Silvana D. Harikedua ${ }^{1}$, Feny Mentang ${ }^{1}$, Grace Sanger ${ }^{1}$ \\ ${ }^{1}$ Program Studi Teknologi Hasil Perikanan, Jurusan Pengolahan Hasil Perikanan, \\ Fakultas Perikanan dan Ilmu Kelautan, Universitas Sam Ratulangi. \\ Jl. Kampus Unsrat Bahu, Manado 95115, Sulawesi Utara, Indonesia. \\ *Penulis Korespondensi: djuhriawonggo@gmail.com \\ (Diterima 22-01-2020; Direvisi 24-07-2020; Dipublikasi 04-08-2020)
}

\begin{abstract}
This study aims to determine the proximate value of Sonneratia alba mangrove flour. The flour was made from young $(\mathrm{d} \leq 3 \mathrm{~cm})$ and old $S$. alba fruit. S. alba fruit were collected from Desa Wori, Kec.Wori, Kab. Minahasa Selatan, North Sulawesi. The measured parameters were moisture content by the oven method, the ash content by the dry ashing method, the protein content by the Kjeldahl method; fat content by the Soxhlet method and carbohydrate content were calculated by difference. The results showed that the proximate content of young $S$. alba fruit flour was $10.53 \%$ of moisture, $5.18 \%$ ash, 8.735 protein, $1.44 \%$ fat and $74.12 \%$ carbohydrate. The proximate content of old $S$. alba mangrove flour was moisture content $9.63 \%$, ash $5.39 \%$, protein $8.34 \%$, fat $1.54 \%$ and carbohydrate $75.1 \%$. Moiture and protein content of young $S$. alba mangrove flour is slightly higher compared to old $S$. alba mangrove flour. Meanwhile, ash, fat and carbohydrate content of old $S$. alba mangrove flour is slightly higher compared to young $S$. alba mangrove flour.

Keywords: mangrove, sonneratia alba, infusion, rendemen, antibacterial.

Penelitian ini bertujuan untuk mengetahui kadar proksimat pada tepung buah mangrove Sonneratia alba muda $(\mathrm{d} \leq 3 \mathrm{~cm})$ dan proksimat tepung buah mangrove $S$. alba tua $(\mathrm{d} \geq 3 \mathrm{~cm})$ yang diambil di Desa Wori Kecamatan Wori Kabupaten Minahasa Utara Sulawesi Utara. Parameter yang dianalisa adalah kadar air dengan metode oven, kadar abu dengan metode pengabuan kering, kadar protein dengan metode kjeldahl meliputi tiga tahap yaitu destruksi, destilasi dan titrasi; kadar lemak dengan metode soxhlet dan kadar karbohidrat dihitung berdasarkan metode (by difference). Hasil penelitian menunjukkan bahwa kandungan proksimat pada tepung buah mangrove $S$. alba muda adalah kadar air 10,53\%, abu 5,18\%, protein 8,735 , lemak $1,44 \%$ dan karbohidrat $74,12 \%$. Kandungan proksimat pada tepung buah mangrove $S$. alba tua adalah kadar air 9,63\%, abu 5,39\%, protein $8,34 \%$, lemak $1,54 \%$ dan karbohidrat $75,1 \%$. Perbandingan kandungan proksimat tepung buah mangrove $S$. alba muda dan tua adalah sebagai berikut: kadar air dan protein pada tepung buah mangrove $S$. alba muda sedikit lebih tinggi dibandingkan dengan tepung buah mangrove $S$. alba tua. sedangkan kadar abu, lemak dan karbohidrat kandungan tepung buah mangrove $S$. alba tua sedikit lebih tinggi dibandingkan dengan tepung buah mangrove $S$. alba muda.
\end{abstract}

Kata kunci: Proksimat, buah Sonneratia alba tua dan muda.

\section{PENDAHULUAN}

Mangrove didefinisikan sebagai tumbuhan berkayu maupun semak belukar yang menempati habitat antara darat dan laut yang secara periodik tergenangi air pasang (Hogarth, 1999). Hutan mangrove merupakan komunitas vegetasi pantai tropis, yang didominasi oleh beberapa jenis mangrove yang mampu tumbuh dan berkembang pada daerah pasang-surut pantai berlumpur.

Di Sulawesi Utara hampir sepanjang pantai Kabupaten Minahasa Utara teridentifikasi tumbuhan mangrove ada 67 jenis dan terdapat 6 jenis mangrove dengan ketebalan hutannya bervariasi. Di Kabupaten Minahasa Utara yang masih memiliki hutan mangrove yang cukup luas dan masih terbilang utuh terdapat di Kecamatan Wori Kabupaten Minahasa Utara Provinsi Sulawesi Utara dengan luas perkiraan sekitar 20 Ha. Menurut Lahabu (2015) Di pesisir Desa Wori, merupakan salah satu desa yang menjadi salah satu lokasi penting sebaran hutan mangrove jenis Sonneratia alba.

S. alba memiliki kulit kayu berwarna putih hingga cokelat. Akar berbentuk kabel di bawah tanah dan muncul ke permukaan sebagai akar nafas yang berbentuk kerucut tumpul dan tingginya mencapai $25 \mathrm{~cm}$. Daun $S$. alba berbentuk bulat ukuran panjang 5-10 cm. Bunga biseksual; gagang 
bunga tumpul panjangnya $1 \mathrm{~cm}$ : terletak di ujung atau pada cabang kecil. Buah $S$. alba seperti bola, ujungnya bertangkai dan bagian dasarnya terbungkus kelopak bunga. Buah mengandung banyak biji (150-200 biji) dan tidak akan membuka pada saat telah matang. Mangrove S. alba dapat mencapai ketinggian hingga 20 meter dengan diameter $40 \mathrm{~cm}$, memiliki sistem perakaran akar napas, seperti biji, kokoh, lancip, diameter pangkal akar mencapai $5 \mathrm{~cm}$. $S$. alba umumnya tumbuh di daerah pertemuan antar sungai dan muara atau teluk berlumpur (Tjitrosoepomo, 2009).

Manfaat langsung dari keberadaan mangrove lainnya adalah sebagai apotik alam, dimana beberapa jenis daun, bunga, buah, akar dan kulit batang pohon mangrove memiliki potensi untuk dimanfaatkan menjadi ramuan obat tradisional yang oleh masyarakat suku Minahasa dikenal dengan sebutan Makatana. Manfaat dari buah mangrove jenis $S$. alba atau padada yaitu buahnya yang asam dapat langsung dimakan atau dibuat cuka, menghasilkan pectin, berkhasiat untuk menambah nafsu makan dan akar nafas sebagai subtitusi gabus dan pelampung (Handayani, 2018). Buah S. alba tidak beracun, tidak memerlukan penanganan khusus dan langsung dapat dimakan. Buah muda dapat dimakan langsung dan dapat dibuat sirup atau jus. Buah yang sudah tua merupakan bahan baku untuk pembuatan kue seperti dodol dan waji. Mangrove jenis pidada (S. alba dan $S$. caseolaris) telah diolah menjadi sembilan bentuk makanan ringan seperti sirup pidada, jus pidada, waji pidada I, waji pidada II, dodol pidada I, dodol pidada II, Permen pidada dan kerupuk buah pidada (Santoso, et.al., 2008).

Menurut Wonggo et. al., (2017) Ekstrak metanol pada buah mangrove S. alba yang diambil di desa Wori Sulawesi Utara mengandung senyawa bioaktif yaitu fenolik, flavonoid, steroid, tritepenoid, saponin, dan tanin. (Dotulong et. al., 2018). Daun mangrove S. alba kering yang diekstrak dengan metanol maupun etanol juga mengandung senyawa bioaktif fenolik, flavonoid, steroid, tritepenoid, saponin dan tanin. (Paputungan et. al., 2017, Putri et. al., 2016) Buah dan daun $S$. alba kering mengandung senyawa bioaktif yaitu fenol, flavonoid, saponin, tanin dan alkaloid.

\section{MATERIAL DAN METODE}

\section{Bahan dan Alat}

Bahan-bahan yang digunakan dalam penelitian ini adalah Bahan baku adalah buah mangrove $S$. alba muda yang berukuran $<3 \mathrm{~cm}$ dan yang tua $\geq 3 \mathrm{~cm}$. Bahan untuk analisa kadar protein: selenium, asam sulfat, $\mathrm{H}_{2} \mathrm{SO}_{4}$, akuades, $\mathrm{NaOH} \mathrm{50 \% ,} \mathrm{HCl}$, indikator mengsel. Bahan untuk analisa kadar lemak: heksana, kertas saring.

Alat-alat yang digunakan dalam penelitian ini adalah kadar air: oven, cawan, desikator, timbangan analitik. Kadar abu: cawan porselin, oven, desikator, tanur pengabuan, timbangan analitik. Kadar protein: timbangan analitik, labu destilasi $(250 \mathrm{ml})$, Gelas ukur $(25 \mathrm{ml}, 50 \mathrm{ml})$, Alat untuk destilasi, Pipet volume $5 \mathrm{ml}$, Buret $25 \mathrm{ml}$, Labu kjedhal. Kadar Lemak: alat soxhlet, labu khusus untuk lemak, oven, timbangan analitik, desikator, penjepit.

\section{Pengambilan dan Preparasi Sampel}

Sampel yang digunakan dalam penelitian ini adalah buah mangrove $S$. alba yang diambil dari Desa Wori Kecamatan Wori Kabuaten Minahasa Utara. Buah mangrove S. alba dikeluarkan kelopaknya, dicuci dengan air mengalir, diiris tipis-tipis kemudian di keringkan selama 2-3 minggu hingga bisa dipatahkan, diblender dan ditapis hingga menghasilkan tepung.

\section{Prosedur Analisa \\ Kadar Air (SNI 01-2891-1992).}

Cawan yang akan digunakan dikeringkan dalam oven pada suhu $100-105^{\circ} \mathrm{C}$ selama 30 menit atau sampai didapat berat tetap. Setelah itu didinginkan dalam desikator selama 30 menit lalu ditimbang. Sampel ditimbang sebanyak 2 gram dalam cawan tersebut lalu dikeringkan dalam oven pada suhu $100^{\circ} \mathrm{C}$ sampai tercapai berat tetap (24 jam). Sampel didinginkan dalam desikator selama 30 menit lalu ditimbang. Perhitungan:

$$
\begin{gathered}
\text { Kadar Air }(\%)=\frac{\mathrm{B} 1-\mathrm{B} 2}{\mathrm{~B} 0} \times 100 \% \\
\text { Ket. B0 = Berat sampel }(\text { gram }) ; \mathrm{B} 1=\text { Berat hasil bobot akhir }(\text { gram }) ; \text { dan B2 = Berat labu }(\text { gram }) .
\end{gathered}
$$




\section{Kadar Abu (SNI 01-2891-1992).}

cawan pengabuan, dibakar dalam tanur, dinginkan dalam desikator dan ditimbang. Cawan pengabuan dikeringkan di dalam oven selama 1 jam pada suhu $105^{\circ} \mathrm{C}$, kemudian didinginkan selama 15 menit di dalam desikator dan ditimbang. Ditimbang sampel sebanyak 2 gram dimasukkan ke dalam cawan pengabuan, kemudian diletakkan dalam tanur pengabuan. Kemudian dibakar sampai didapat abu berwarna abu-abu atau sampai beratnya tetap. Pengabuan dilakukan pada suhu $550^{\circ} \mathrm{C}$ selama 3 jam. Dinginkan dalam desikator, kemudian ditimbang. Perhitungan:

$$
\text { Kadar Abu (\%) }=\frac{\text { Bobot setelah tanur }(\mathrm{g}) \text {-Cawan kosong }(\mathrm{g})}{\text { Berat sampel awal }(\mathrm{g})} \times 100 \%
$$

\section{Kadar Protein (SNI 01-2986-1992). \\ Dekstruksi}

Ditimbang $1 \mathrm{~g}$ sampel, kemudian dimasukan ke dalam labu Kjeldahl $100 \mathrm{ml}$. ditambahkan 5 g campuran selenium dan $25 \mathrm{ml} \mathrm{H}_{2} \mathrm{SO}_{4}$ pekat. Dipanaskan di atas pemanas listrik atau api pembakar sampai mendidih dan larutan menjadi jernih kehijau-hijauan. dibiarkan dingin. diencerkan dan dimasukan ke dalam labu ukur $100 \mathrm{ml}$ sampai pada tanda garis.

\section{Pembuatan blanko:}

Diambil $25 \mathrm{ml} \mathrm{H}_{2} \mathrm{SO}_{4}$ kemudian ditambahkan akuades $150 \mathrm{ml}$ dan ditambahkan 3 tetes indikator PP.

\section{Destilasi}

Dipipet $5 \mathrm{ml}$ larutan sampel dan dimasukan ke dalam alat penyuling, Ditambahkan $5 \mathrm{ml}$ $\mathrm{NaOH} 30 \%$ Dan beberapa tetes PP. Disuling selama 10 menit, pada penampungan digunakan $10 \mathrm{ml}$ larutan asam borat $2 \%$ yang telah dicampur indicator. dibilasi ujung pendingin dengan air suling. Distilasi juga dilakukan pada blanko.

\section{Titrasi}

Distilat kemudian dititrasi dengan larutan $\mathrm{HCl} 0,01 \mathrm{~N}$. Perhitungan:

$$
\text { Kadar Protein }(\%)=\frac{(\mathrm{V} 1-\mathrm{V} 2) \times \mathrm{N} \times 0,014 \times \mathrm{fk} \times \mathrm{fp}}{\mathrm{W}} \times 100 \%
$$

Ket. $\mathrm{W}=$ bobot cuplikan; $\mathrm{V} 1=$ Volume $\mathrm{HCl} 0,01 \mathrm{~N}$ yang digunakan penitraan contoh; $\mathrm{V} 2=$ Volume $\mathrm{HCl}$ yang digunakan penitraan blanko; $\mathrm{N}=$ normalitas $\mathrm{HCl} ; \mathrm{Fk}=$ faktor konversi untuk protein dari makanan secara umum $: 6,25 ; \mathrm{Fp}=$ faktor pengenceran.

\section{Kadar Lemak (SNI 01-2891-1992).}

Labu lemak yang akan digunakan dikeringkan dalam oven bersuhu $105^{\circ} \mathrm{C}$ selama $1 \mathrm{jam}$. Kemudian Labu lemak didinginkan dalam desikator selama 15 menit dan ditimbang. Sampel sebanyak \pm 5 gram dihaluskan kemudian ditimbang dan dibungkus menggunakan kertas saring yang dibentuk selongsong. Dirangkai alat ekstraksi dari heating mantle, labu lemak, soxhlet hingga kondensor. Sampel kemudian dimasukkan ke dalam soxhlet yang kemudian ditambahkan pelarut heksan $250 \mathrm{ml}$. Ekstraksi dilakukan selama \pm 6 jam sampai pelarut turun kembali melalui sifon ke dalam labu lemak berwarna jernih. Hasil ekstraksi dari labu lemak dipisahkan antara heksan dan lemak. Lemak yang sudah dipisahkan dengan heksan kemudian dipanask an kedalam oven dengan suhu $105^{\circ} \mathrm{C}$ selama 1 jam. Labu lemak didinginkan dalam desikator selama 15 menit dan ditimbang. Dilakukan pemanasan kembali ke dalam oven selama 1 jam, apabila selisih penimbangan hasil ekstrasi terakhir dengan pertimbangan sebelumnya belum mencapai 0,0002 gram. Persentase kadar lemak dihitung dengan rumus:

$$
\begin{gathered}
\text { Kadar Lemak }(\%)=\frac{\mathrm{W} 3-\mathrm{W} 2}{\mathrm{~W} 1} \times 100 \% \\
\text { Ket. W1 = Berat sampel }(\mathrm{g}) ; \mathrm{W} 2=\text { Bobot labu lemak kosong }(\mathrm{g}) ; \text { dan W3 = Bobot hasil penimbangan akhir }(\mathrm{g}) .
\end{gathered}
$$

\section{Kadar Karbohidrat}

Karbohidrat (By difference). Dilakukan menggunakan metode by difference yaitu pengurangan $100 \%$ dengan jumlah dari hasil empat komponen yaitu kadar air, abu, protein dan lemak. Perhitungannya sebagai berikut: 
Kadar Karbohidrat $=100 \%-(\%$ kadar air $+\%$ kadar abu $+\%$ Protein $+\%$ lemak $)$

\section{HASIL DAN PEMBAHASAN}

\section{Kadar Air}

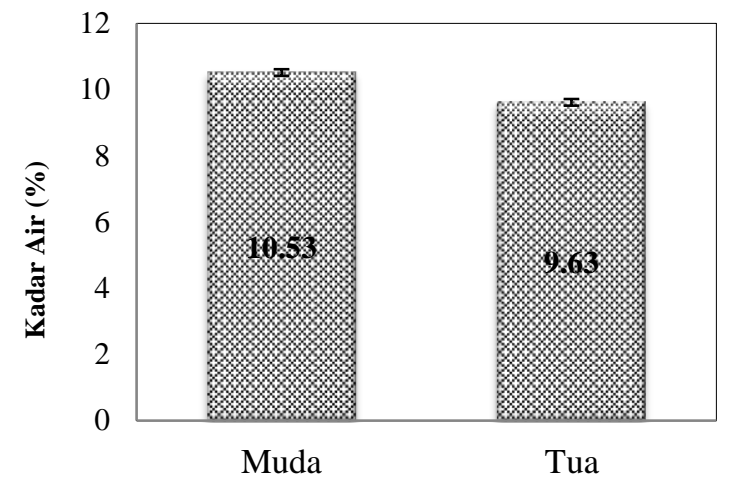

Gambar 1. Kadar air tepung buah mangrove Sonneratia alba.

Gambar 1 menunjukkan bahwa kadar air tepung buah mangrove $S$. alba lebih tinggi buah muda $10,53 \%$ dibanding buah tua 9,63\%. Menurut (Amanu, 2014) Air dapat melarutkan berbagai bahan seperti garam, vitamin yang larut air, mineral dan senyawa citarasa. Banyaknya kandungan air dalam bahan pangan merupakan salah satu faktor yang mempengaruhi kecepatan dan aktivitas enzim, mixroba dan kimiawi, yaitu terjadi ketengikan, reaksi non enzimatis sehingga menimbulkan sifat-sifat organoleptik, penampakkan, tekstur dan cita rasa gizi yang berubah.

\section{Kadar Abu}

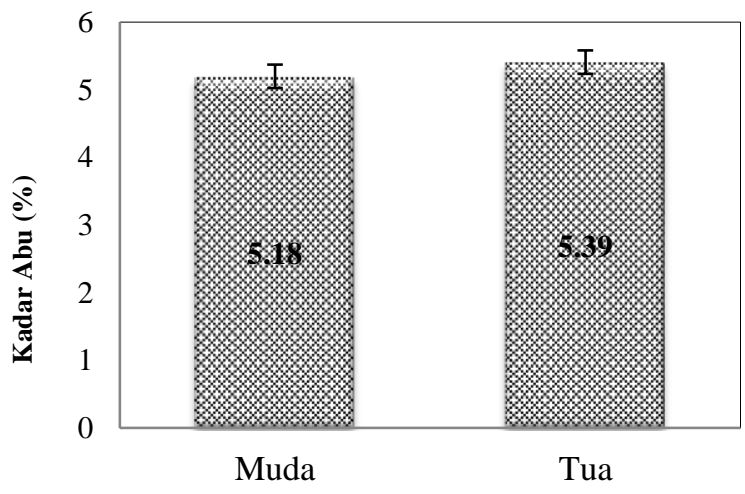

Gambar 2. Kadar abu tepung buah mangrove Sonneratia alba.

Gambar 2 menunjukkan bahwa kadar abu tepung buah mangrove $S$. alba lebih tinggi buah tua 5,39\% dibanding buah muda 5,18\%. Menurut Astuti (2011) kadar abu merupakan campuran dari komponen anorganik atau mineral yang terdapat pada suatu bahan pangan. Bahan pangan terdiri dari 96\% bahan anorganik dan air, sedangkan sisanya merupakan mine ral. Mineral organik dikenal sebagai kadar abu. Penentuan kadar abu total dapat digunakan untuk berbagi tujuan, antara lain untuk menentukan baik atau tidaknya suatu pengolahan, mengetahui jenis bahan yang digunakan, dan sebagai penentu parameter nilai gizi suatu bahan makanan.

\section{Kadar Protein}

Gambar 3 menunjukkan bahwa kadar protein tepung buah mangrove $S$. alba lebih tinggi buah muda 8,73\% dibanding buah tua 8,34. Menurut Muchtadi (2010) protein merupakan suatu senyawa yang dibutuhkan dalam tubuh manusia sebagai zat pendukung pertumbuhan dan perkembangan. Dalam protein terdapat sumber energi dan zat pengatur jaringan tubuh. Protein juga berguna sebagai biokatalisator enzim dalam proses kimia. Protein biasanya didapat dari makanan yang kita konsumsi, baik dari hewan maupun tumbuhan. 


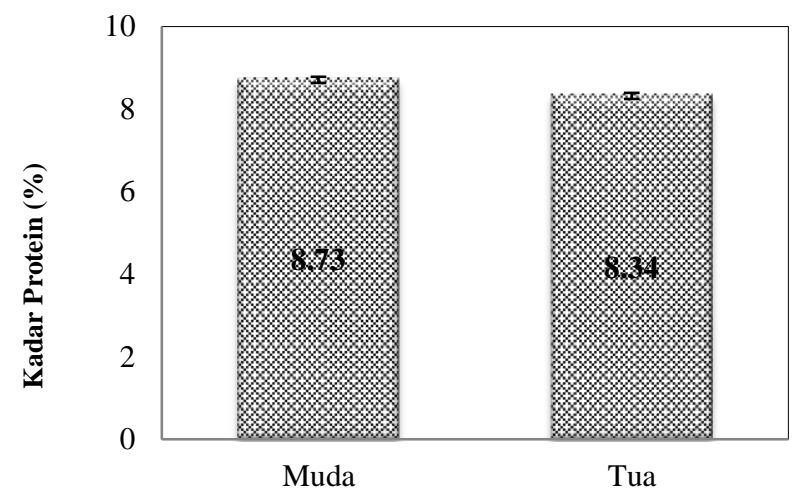

Gambar 3. Kadar protein tepung buah mangrove Sonneratia alba.

\section{Kadar Lemak}

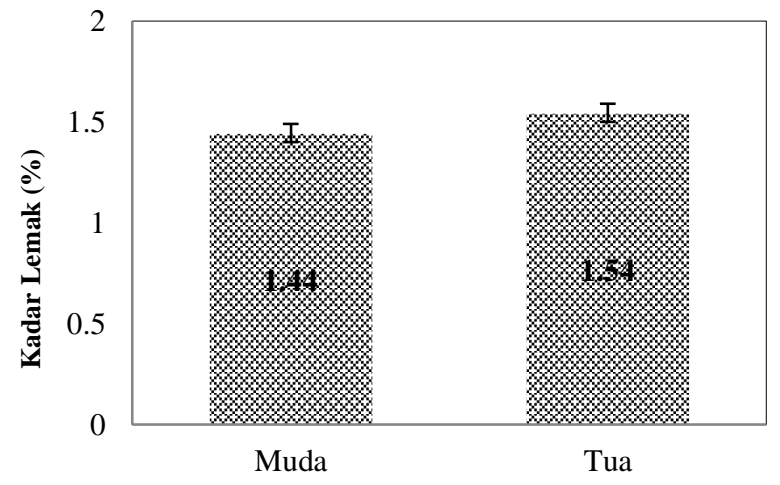

Gambar 4. Kadar lemak tepung buah mangrove Sonneratia alba.

Gambar 4 menunjukkan bahwa kadar lemak tepung buah mangrove $S$. alba lebih tinggi buah tua $1,54 \%$ dibanding buah muda $1,44 \%$. Menurut Hermanto (2010). Lemak dan minyak terdapat pada hampir semua jenis bahan pangan dan masing-masing mempunyai jumlah kandungan yang berbeda-beda. Oleh karena itu analisis kadar lemak suatu bahan pangan sangat penting dilakukan agar kebutuhan kalori suatu bahan makanan bisa diperhitungkan dengan baik. Lemak khususnya minyak nabati, mengandung asam lemak esensial seperti asam linoleat, linolenant dan arakidonat yang dapat mencegah penyempitan pembuluh darah akibat penumpukan kolestrol.

\section{Kadar Karbohidrat}

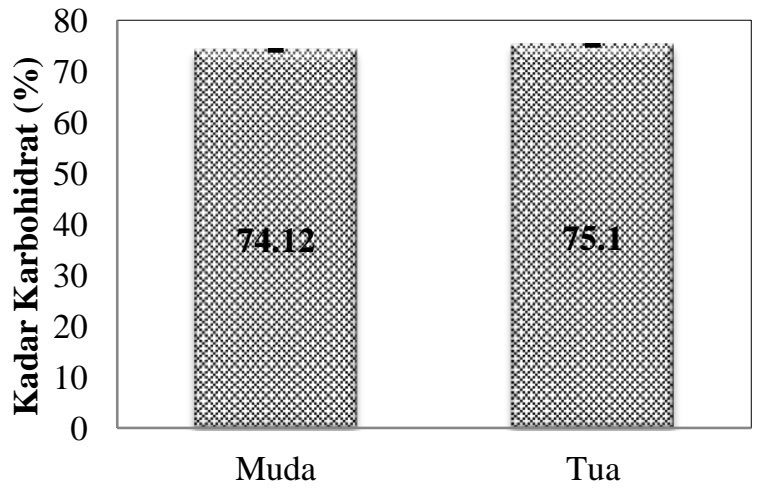

Gambar 5. Kadar karbohidrat tepung buah mangrove Sonneratia alba.

Gambar 5 menunjukkan bahwa kadar karbohidrat tepung buah mangrove $S$. alba lebih tinggi buah tua $75,1 \%$ dibanding buah muda74,12\%. Menurut Almatsier (2004), karbohidrat dapat dibedakan menjadi dua jenis yaitu karbohidrat sederhana dan karbohidrat kompleks. Karbohidrat sederhana dapat ditemui dalam produk pangan seperti madu, buah-buahan dan susu. Karbohidrat kompleks dapat ditemui dalam produk pangan seperti nasi, kentang, jagung, roti dan lainnya karbohidrat kompleks yaitu pati, glikogen, selulosa, dan serat. (Winarno, 2002) karbohidrat merupakan sumber kalori utama bagi hampir seluruh penduduk dunia, Khususnya bagi penduduk 
negara yang sedang berkembang. Karbohidrat mempunyai peranan penting dalam menentukan karakteristik bahan pangan, misalnya rasa, warna, tekstur dan lain-lain. Sedangkan dalam tubuh, karbohidrat berguna untuk mencegah timbulnya ketosis, pemecahan protein tubuh yang berlebih an, kehilangan mineral dan berguna untuk membantu metabolisme lemak dan protein.

\section{KESIMPULAN}

\section{Kesimpulan}

Kandungan proksimat pada buah Sonneratia alba muda adalah kadar air 10,53\% , abu $5,18 \%$, protein 8,735 , lemak $1,44 \%$ dan karbohidrat $74,12 \%$. Kandungan proksimat pada buah $S$. alba tua adalah kadar air 9,63\%, abu 5,39\%, protein 8,34\%, lemak 1,54\% dan karbohidrat 75,1\%. Kandungan proksimat tepung buah mangrove $S$. alba muda kandungan kadar air dan protein pada tepung buah mangrove $S$. alba lebih sedikit lebih tinggi dibandingkan dengan tepung buah mangrove $S$. alba tua. sedangkan kadar abu lemak dan karbohidrat kandungan tepung buah mangrove $S$. alba tua lebih tinggi sedikit di bandingkan dengan tepung buah mangrove $S$. alba muda. Perlu dilakukan analisa lanjutan tentang jenis karbuhidrat pada buah Sonneratia alba.,apakah termasuk karbohidrat sederhana atau kompleks.

\section{DAFTAR PUSTAKA}

Almatsier, S. 2004 . Prinsip Dasar Ilmu Gizi . Gramedia Pustaka Utama . Jakarta

Dotulong, V., Wonggo, D., \& Montolalu, L. A. D. Y. (2018). Phytochemical Content, Total Phenols, and Antioxidant Activity of Mangrove Sonneratia alba Young Leaf Through Different Extraction Methods and Solvents. International Journal of ChemTech Research, 11(11), 356-363.

Handayani, S. (2019). Identifikasi Jenis Tanaman Mangrove Sebagai Bahan Pangan Alternatif Di Kabupaten Sidoarjo Jawa Timur. Jurnal Teknologi Pangan, 12(2), 33-46.

Hogarth, P. J. 1999. The Biology of Mangroves and Seagrasses. Oxford University Press Inc. New York.

Lahabu, Y., Schaduw, J. N., \& Windarto, A. B. (2015). Kondisi Ekologi Mangrove Di Pulau Mantehage Kecamatan Wori Kabupaten Minahasa Utara Provinsi Sulawesi Utara. Jurnal Pesisir dan Laut Tropis, 3(2), 41-52

Muchtadi, D. 2010. Kedelai: Komponen Bioaktif Untuk Kesehatan. Alfabeta. Bandung

Paputungan, Z., Wonggo, D., \& Kaseger, B. E. (2017). Uji Fitokimia Dan Aktivitas Antioksidan Buah Mangrove Sonneratia alba Di Desa Nunuk Kecamatan Pinolosian Kabupaten Bolaang Mongondow Selatan Sulawesi Utara. Media Teknologi Hasil Perikanan, 5(3), 96-102.

Putri, R. R., Hasanah, R., \& Kusimaningrum, I. (2016). Uji aktivitas antibakteri dan Uji fitokimia ekstrak daun mangrove Sonneratia alba. Aquawarman Jurnal Sains Dan Teknologi Akuakultur, 2(1), 43-50.

Santoso, U. (2008). Hutan mangrove, permasalahan dan solusinya. Jurnal Pengembangan Peternakan Tropis, 3.

[SNI] Standar Nasional Indonesia. (2009). Tepung terigu sebagai bahan makanan. SNI-01-3751-2009, Badan Standarisasi Nasional, Jakarta.

[SNI] Standar Nasional Indonesia. (1992). SNI 01-2891-1992 Cara Uji Makanan dan Minuman. Badan Standardisasi Nasional. Jakarta.

Wonggo, D., Berhimpon, S., Kurnia, D., \& Dotulong, V. (2017). Antioxidant activities of mangrove fruit (Sonneratia alba) taken from Wori Village, North Sulawesi. Indonesia Int. J. ChemTech Res, 10, 284-90.

Winarno, F.G. 2002.Kimia Pangan dan Gizi. Gramedia Pustaka Utama. Jakarta 